\title{
ADMINISTRATIVE ADOPTION PATTERN AMONG THE RICE MILL ENTREPRENEURS IN TIRUPUR DISTRICT
}

\author{
Mrs.P.Nalini, Associate Professor, Department of Management, Builders Engineering College. \\ Dr.G.Barani, Associate Professor, Bharathiar School of Management and Entrepreneur \\ Development, Bharathiar University.
}

\begin{abstract}
As the highest source of nourishment for over half the world's population, rice is by far one of the most essential commercial food crops. Its yearly yield worldwide is approximately 535 million tons. Fifty countries yield rice, with China and India they are supportive $50 \%$ of total production. In order to be successful in planning, organizing, leading, and controlling, rice mill entrepreneurs must use a wide variety of skills. A skill is the ability to do something proficiently. Administrative skills fall into three basic categories: technical, human relations, and conceptual skills. In this study, administrative adoption among the rice mill entrepreneurs in Tirupur district was studied with one hundred respondents. The researcher has collected one hundred samples in Tirupur district by means of using questionnaire. Being a successful entrepreneur means more than starting new ventures every other day. It means the right attitude towards a business and the determination and grit to achieve success. A successful entrepreneur has a strong inner drive that helps him or her to succeed. Rice mill entrepreneurs should constantly reinvent themselves and think of better ways to run a business and improvise on the products and services offered by them.
\end{abstract}

\section{Keywords: Rice, Population, Entrepreneurs, Skills, Technical.}

\section{INTRODUCTION}

Rice mill Entrepreneurs have a critical role to play in shaping the futures of the economies of nations. By creating value through starting businesses and ventures, they ensure that the wealth of the nation's increases. Similarly, by exporting goods and services, they ensure that the economies earn valuable foreign exchange that is vital for the countries to import the 
necessary goods and services. In addition, by creating jobs, they ensure that the people in the nations are gainfully employed. Moreover, through their social causes and championing of public good endeavors, they actualize sustainability, social justice, and environmental responsibility. Perhaps the biggest contribution or the underlying theme that runs through all these contributions is their innate ability to innovate that ensures speedy and efficient development of nations and their economies. One of the key requirements for entrepreneurial success is ability to develop and offer something unique to the marketplace and adopting administration skills. Over time, entrepreneurship has become associated with creativity, the ability to develop something original, particularly an idea or a representation of an idea. Innovation requires creativity, but innovation is more specifically the application of creativity. Innovation is the manifestation of creativity into a usable product or service. In the entrepreneurial context, innovation is any new idea, process, or product, or a change to an existing product or process that adds value to that existing product or service. The administrative framework can significantly affect the success of innovative rice mill entreprises when they seek to enter markets and also to grow. High barriers to entry can effectively discourage the creation and expansion of new companies. Substantial resources can be diverted to dealing with administrative issues instead of being invested in innovation. Moreover, such barriers can negatively affect markets by reducing competition and inhibiting innovative business activities. This study mainly aimed to know the administration adoption among the rice mill entrepreneurs in Tirupur District.

\section{MATERIALS AND METHODS}

Bell et al. (2000) have conducted principles and some lesions in rice quality management; the quality of milled rice is low due to inappropriate management techniques in all aspects of grain handling, including harvesting, threshing, drying and milling. So far there has been little emphasis on quality management in the postproduction sector, and many key players were not aware of the general principles for maintaining grain quality. These principles were simple in essence as they largely relate to management of grain moisture content throughout the post production system. For example, grain quality can be improved by mechanical threshing at 20 $24 \%$ moisture content to prevent grain damage, by timely drying down to $14 \%$ moisture content to minimise grain spoilage, and by avoiding re-absorption of moisture during storage to prevent fissuring. If these principles were applied on a broader scale, large improvements in grain quality 
could be accomplished irrespective of the technology involved. Joseph et al. (2012) conducted on factors influencing rice production in Igbemo-Ekiti region of Nigeria. It does so in the context of African Regional Requirement for Food Security and Economic Development (ARFSED). 146 respondents were selected from the 21 residential quarters of the region, using the multiple linear regression model for analysis, the study discovered that the status of the rice farmers, area of land cultivated, availability of market for the rice products, the number of laborers engaged in production and the use of agro-chemicals are crucial factors impacting production. The path to success lies in evolution, whether it is evolution of ideas, services and products or technology. An entrepreneur should have an open mind and eagerness to learn new things. It is imperative to understand that the only way to keep at the top is to keep on changing and evolving with the time. An entrepreneur should be aware of the latest service techniques and technology in order to serve the clients in a better way.

Methodology is a way to systematically solve the research problems. It explains the various steps that are generally adopted by the researcher in studying the research problems along with the logic behind it. This study has used both primary data and secondary data. For collecting primary data field survey technique was undertaken in the study. The researcher has collected one hundred samples in Tirupur district by means of using questionnaires. In this study, descriptive research design is made use of which describes the demographic characteristics of rice mill entrepreneurs. The respondents were selected on the basis of simple random sampling technique. The technique was adopted for collecting the primary data from the respondents. Multiple regression analysis was used for further analysis. A multiple regression is a statistical instrument used to find out the correlation between two or more variables. One variable is caused by the performance of another one. The former variable is coined as independent and the latent variable is coined as the dependent. While there are two or more independent variables, the study that shows the correlation between the two is called as multiple regression analysis

\section{RESULTS AND DISCUSSIONS}

The foremost purpose of using this multiple regression analysis is to forecast the inconsistency of the dependent variable based on its co-variants with all the independent variables. It is useful to expect the level of dependent phenomenon through multiple regression 
analysis, if the levels of independent variables are known. The multiple regression analysis shows the association between level of administration adoption among the rice mill entrepreneurs in Tirupur District and thirteen independent variables that were studied. The analysis found that among these thirteen variables, gender, experience, ownership type and mode of ownership was closely associated with the level of administration adoption among the rice mill entrepreneurs. In order to evaluate the interdependence of independent variables and their total contribution to the level of administration adoption among the rice mill entrepreneurs, the results of the analysis were put into multiple regression analysis, and comprehensive results are given in the following table.

TABLE 1

ADMINISTRATION ADOPTION AMONG THE RICE MILL ENTREPRENEURS (MULTIPLE REGRESSION ANALYSIS)

\begin{tabular}{|c|l|c|c|c|c|c|}
\hline S.No. & \multicolumn{1}{|c|}{ Variables } & B & $\begin{array}{c}\text { Std. } \\
\text { Error }\end{array}$ & Beta & T & Sig \\
\hline & (Constant) & .878 & .689 & & 1.273 & .206 \\
\hline 1 & Location of mill & -.200 & .252 & -.078 & -.791 & .431 \\
\hline 3 & Age & -.027 & .113 & -.023 & -.242 & .809 \\
\hline 4 & Gender & .325 & .094 & .336 & 3.450 & .001 \\
\hline 5 & Experience & -.194 & .071 & -.247 & -2.727 & .008 \\
\hline 6 & Ownership type & .476 & .154 & .279 & 3.095 & .003 \\
\hline 7 & Number of mills own & .243 & .207 & .107 & 1.173 & .244 \\
\hline 8 & $\begin{array}{l}\text { Membership position in } \\
\text { rice mill association }\end{array}$ &. .290 & .242 & -.103 & -1.197 & .234 \\
\hline 9 & $\begin{array}{l}\text { Generation of } \\
\text { entrepreneur }\end{array}$ & .027 & .103 & .024 & .267 & .790 \\
\hline 10 & Educational qualification & .039 & .061 & .057 & .634 & .528 \\
\hline 11 & Income per annum & -.021 & .115 & -.016 & -.186 & .853 \\
\hline 12 & Wealth position & .005 & .072 & .007 & .074 & .941 \\
\hline 13 & $\begin{array}{l}\text { Production turnover per } \\
\text { annum }\end{array}$ & .002 & .086 & .003 & .028 & .977 \\
\hline & & & & & & .043 \\
\hline
\end{tabular}


TABLE 2

R-VALUE

\begin{tabular}{|c|c|c|c|c|}
\hline Model & $\mathbf{R}$ & $\mathbf{R}^{\mathbf{2}}$ Square & $\begin{array}{c}\text { Adjusted R } \\
\text { Square }\end{array}$ & $\begin{array}{c}\text { Std. Error of the } \\
\text { Estimate }\end{array}$ \\
\hline 1 & $.622^{\mathrm{a}}$ & .387 & .294 & .647 \\
\hline
\end{tabular}

The multiple linear regression component (Dependent Variable) is found statistically a good fit as $\mathrm{R}^{2}$ is 0.387 which shows that the four independent variables (gender, experience, ownership type and mode of ownership) contribute about $38.7 \%$ on the variations in administration adoption among the rice mill entrepreneurs and this is statistically significant at 1 and 5\% level.

The table indicates that the co-efficient of respondents in gender, ownership type, number of mills own, mode of ownership, generation of entrepreneur, educational qualification, wealth position and production turnover per annum are positively associated with the level of administration adoption among the rice mill entrepreneurs. Further, it infers that these variables contribute to the administration adoption among the rice mill entrepreneurs are statistically a good fit. The variables such as gender, experience, ownership type and mode of ownership is significant at $1 \%$ and $5 \%$ level which implies that their influence is most significant than the remaining variables.

The increasing rate of level of administration adoption among the rice mill entrepreneurs shows enhanced results of the independent variables such as gender with 0.325 unit change, with 0.476 unit change in ownership type, with 0.243 unit change in number of mills own, with 0.416 unit change in mode of ownership, with 0.027 unit change in generation of entrepreneur, with 0.039 unit change in educational qualification, with 0.005 unit change in wealth position and with 0.002 unit change in production turnover.

\section{TABLE 3}

ANOVA

\begin{tabular}{|c|c|c|c|c|c|c|}
\hline \multicolumn{2}{|c|}{ Model } & Sum of Squares & df & Mean Square & F & Sig. \\
\hline \multirow{3}{*}{1} & Regression & 22.730 & 13 & 1.748 & 4.173 & $.000^{\mathrm{b}}$ \\
\cline { 2 - 7 } & Residual & 36.030 & 86 & .419 & & \\
\cline { 2 - 7 } & Total & 58.760 & 99 & & & \\
\hline
\end{tabular}


The above table shows the $\mathrm{F}$ value which is significant at $1 \%$ level. Therefore, from the investigation, the following observations could be made. The variables such as gender, ownership type, number of mills own, mode of ownership, generation of entrepreneur, educational qualification, wealth position and production turnover per annum are positively associated with the level of administration adoption among the rice mill entrepreneurs. Further, it infers that these variables contribute to the administration adoption among the rice mill entrepreneurs are statistically a good fit. The variables such as gender, experience, ownership type and mode of ownership is significant at $1 \%$ and $5 \%$ level which implies that their influence is most significant than the remaining variables.

\section{RECOMMENDATIONS AND CONCLUSION}

A successful entrepreneur always has a strong sense of self-confidence and a healthy opinion of their skills and abilities. Their personality is assertive and strong. They are always focused and do not dilly dally with the issues at hand. This is what makes them different from the rest. Administrative adoption of rice mill entrepreneurs has a great impact on their success. They should always be on the lookout for new innovations and ideas in order to emerge as a winner. Employees are an important resource for rice mills. These individuals help firms absorb and deploy firm-specific knowledge that aids the mill in developing competitive advantage. Administrative adoption impacts employees from several different points of view. In order to attract and retain the best employees rice mill entrepreneurs need to continuously motivate and challenge their work force. When employees are empowered within their organizations they experience increased motivation. Participation in new product or process development activities can provide employees with the challenges that they require to remain motivated and actively engaged in the activities taking place within the organization. An entrepreneur should be excited by the prospect of work. They should always have a strong drive to succeed and overcome obstacles. They should not only set big goals for themselves but also see that they are actually committed to achieving them regardless of the countless setbacks that occur. When developing administrative adoption within a rice mill, employees must be given a certain level of autonomy to allow them the freedom to develop and capitalize on the new ideas that they may uncover. While the development of administrative adoption within a rice mill might be the best approach to drawing out innovation within employees, rice mill entrepreneurs should utilize 
deliberate measures to achieve success. Finally, rice mill entrepreneurs should constantly reinvent themselves and think of better ways to run a business and improvise on the products and services offered by them.

\section{REFERENCES}

1. Ahuja, G., and Lambert, C. M., (2001), "Entrepreneurship in the Large Corporation: A Longitudinal Study of How Established Firms Create Breakthrough Inventions, Strategic Management Journal, Vol.22(607), pp.521-543.

2. Amrutha, C.P., (1994), "Economics of Processing Paddy into Rice, Poha, Murmura and Popped Rice", M.Sc, Agriculture Thesis, University of Agricultural Sciences, Bangalore India.

3. Arun, K., and Dilip, K., (2011), "Problems and Prospects of Women Entrepreneurs in India”, Global Economic Research, Vol.1 (1), pp. 151-159.

4. Bell, M. A., Bakker, R.R., De Padua, D.B., and Rickman, J., (2000), "Rice Quality Management - Principles and Some Lessons”, Quality Assurance in Agricultural Produce, edited by G.I. Johnson, Le Van To, Nguyen Duy Duc and M.C. Webb., ACIAR Proceedings 100, pp.255-263.

5. Flora, C. B., (2006), “Are Entrepreneurs Born or Made?”, Rural Development News, Vol.28 (4), pp.1-3.

6. Joseph O. Basorun and Julius O. Fasakin, (2012), "Factors Influencing Rice Production in Igbemo-Ekiti Region of Nigeria", Journal of Agriculture, Food and Environmental Sciences, Vol.5 (1), pp.1-9.

7. Peltola, S., (2012), “Can an Old Firm Learn New Tricks? A Corporate Entrepreneurship Approach to Organization Renewal" Business Horizons, 55: pp.43-51.

8. Qureshi, S., Mian, S.A., and Rana, A.I., (2010), "Behavioral Characteristics of Entrepreneurs in the Gujrat, Gujranawala and Slalkot Industrial Clusters of Pakistan: A Comparison of First, Second and Third Generation Family Firms”, International Journal of Business and Social Science, Vol.1(2) pp.80-88.

9. Sujata, K., Vandana K., and Neeta L., (2010).।, "Problems Faced by Rural Women Entrepreneurs of Rajasthan", Study of Home Communication Science, Vol.4 (2), pp.115119. 
10. Nalini. P., and Barani. G., (2020 ), "A Study on Issues Faced by Rice Mill Entrepreneurs", Journal of Information and Computational Science, Vol.10 (2), pp.121132. 